Fordham Law School

FLASH: The Fordham Law Archive of Scholarship and History

\title{
Rethinking The Global Anti-Money Laundering Regulations to Deter Corruption
}

Sungyong Kang

Fordham University School of Law

Follow this and additional works at: https://ir.lawnet.fordham.edu/sjd

\section{Recommended Citation}

Kang, Sungyong, "Rethinking The Global Anti-Money Laundering Regulations to Deter Corruption" (2017). SJD Dissertations. 15.

https://ir.lawnet.fordham.edu/sjd/15

This Dissertation (one of three articles) is brought to you for free and open access by the Academics at FLASH: The Fordham Law Archive of Scholarship and History. It has been accepted for inclusion in SJD Dissertations by an authorized administrator of FLASH: The Fordham Law Archive of Scholarship and History. For more information, please contact tmelnick@law.fordham.edu. 


\title{
RETHINKING THE GLOBAL ANTI-MONEY LAUNDERING REGULATIONS TO DETER CORRUPTION
}

\author{
Sungyong Kang*
}

This article is Submitted Manuscript Under Review(SMUR) version. This article has been published in a revised form subsequent to editorial input by the International and Comparative Law Quarterly editors as follows :

https://www.cambridge.org/core/journals/international-and-comparative-lawquarterly/article/rethinking-the-global-antimoney-laundering-regulations-to-detercorruption/88B3E5EA6FBA96F4057BB9214D904A6A

\footnotetext{
* S.J.D., Attorney at Law Licensed in New York, Inspector at the Korea National Police Agency.
} 


\section{INTRODUCTION}

"Friday was hell for me . . . I had all my money frozen. I am being treated like a criminal."”

That was the reaction of Mr. Ocampo, the former finance minister of Colombia and a former World Bank presidential nominee, when his bank account was terminated just because of his status as a Politically Exposed Person (PEP).

The United Nations Convention Against Corruption (UNCAC) first introduced the concept of PEPs in 2003 - without distinction between domestic and foreign officials - as part of Anti-Money Laundering (AML) regulations to address potential proceeds of corruption being laundered through financial institutions. It required financial institutions to exercise Enhanced Due Diligence (EDD) against PEPs in carrying out their duty to provide Suspicious Activities Reports (SAR) to a government. ${ }^{2}$ In the same year, the Financial Action Task Force (FATF) provided for the regulation of foreign PEPs in its '40 Recommendations' that have been widely adopted as the AML standard by more than 190 jurisdictions. ${ }^{3}$ Other intergovernmental and private entities have also adopted their own standards for PEP regulation. ${ }^{4}$

\footnotetext{
1 Tom Braithwaite \& John Paul Rathbone \& Gina Chon, JPMorgan shuts foreign diplomats' accounts, FINANCIAL TIMES (May 6, 2014), available at https://www.ft.com/content/3a8f975c-d523-11e3-adec00144feabdc0 (last visited Mar.23, 2017).

2 United Nations Convention Against Corruption, art.52.1, Oct. 31, 2003, A/58/422.

3 See Financial Action Task Force [FATF], FATF 40 Recomendations, Recommendation 5, at 5 (2003), available at http://www.fatfgafi.org/media/fatf/documents/FATF\%20Standards\%20-\%2040\%20Recommendations\%20rc.pdf; FATF, Countries, http://www.fatf-gafi.org/countries/ (last visited Mar. 23, 2017).

4 A qausi-public organization (e.g. The Basel Committee on Banking Supervision) and a private organization (e.g. Wolfsberg Group) came up with its own AML/PEP standard. See e.g., Basel Committee on Banking Supervision, A brief history of the Basel Committee, at 1 (July 2013), available at http://www.bis.org/bcbs/history.pdf; The Wolfsberg Group, Global Banks: Global Standards, http://www.wolfsberg-principles.com/index.html (last visited Mar. 23, 2017).
} 
While such global AML/PEP regulations set by diverse types of global regulatory bodies aim to detect and deter corrupt PEPs, they can have a tremendously negative impact on many innocent PEPs, particularly foreign PEPs, as illustrated in the anecdote of Mr. Ocampo in the United States. Following these global standards, US AML legislation requires financial institutions to apply EDD against foreign PEPs. ${ }^{5}$ Both the global and domestic PEP regulations themselves do not require financial institutions to terminate the relationship with PEPs but only to apply EDD. However, due to the significant compliance costs of identifying PEPs coupled with an increased risk of serious fines against compliance failures, financial institutions have voluntarily made business judgements to terminate. For instance, in 2014, JPMorgan simply chose to close the Chase accounts and stop serving all current and former non-US senior government officials. ${ }^{6}$ HSBC has taken a similar path against foreign officials, including diplomats in the US, for years. ${ }^{7}$

Detection and deterrence of corruption through AML/PEP regulation does not necessarily cause such collateral damage to innocent PEPs. Actually, AML/PEP regulation could avoid, or at least minimize, the collateral damage while maximizing deterrence of corruption, if high degrees of coordination along two dimensions are satisfied: the trans-border, and between public enforcement entities and private actors. In other words, the first dimension requires AML/PEP regulations to be harmonized at the global level; the second dimension demands the harmonized global AML/PEP regulations to embrace two-way information sharing between a government and private financial institutions instead of one-way reporting by financial institutions to a government.

\footnotetext{
31 U.S.C. $\$ 5318$ (2012).

6 Supra note 1.

7 Id.
} 
However, fairly large discrepancies, both in substantive and procedural rules, exist among the global standards of AML/PEP regulation. These discrepancies lead to variance in the compliance rate of states with AML/PEP regulation generating overall a low compliance rate. ${ }^{8}$ As correctly pointed out by the World Bank, "the current variations among approaches serve as both a good excuse not to act and are seen by some as a real impediment to the development and implementation of effective PEPs controls." $" 9$

The cornerstone change to fulfil high degrees of coordination along the dimensions was made in February 2012 by the inclusion of domestic PEPs in FATF Recommendations. ${ }^{10}$ With regards to the first dimension, though gaps on the precise definition of PEPs still remain, ${ }^{11}$ the recommendation reconciled the main substantive discrepancy on the scope of PEPswhether to embrace domestic PEPs in addition to foreign PEPs-in global AML/PEPs standards. In addition, information on domestic PEPs, unlike foreign PEPs, is information in possession of governments as it mainly concerns its own employees and officials. Accordingly, the inclusion of domestic PEPs into FATF Recommendations also provided a foundation for coordination along the second dimension: forming two-way information sharing by providing requisite governmental information — domestic PEPs lists—-to financial institutions with a duty to report suspicions of corruption to the government.

\footnotetext{
8 See Theodore S. Greenberg \& Larissa Gray, et al., Stolen Asset Recovery, Politically Exposed Persons: A Policy Paper on Strengthening Preventive Measures, at 7, 17 (2009) available at http://siteresources.worldbank.org/EXTSARI/Resources/5570284-1257172052492/PEPsful.pdf?resourceurlname=PEPs-ful.pdf.

9 Id. at Xv.

10 See FATF, International Standards on Combating Money Laundering and the Financing of Terrorism \& Proliferation: The FATF Recommendations, Recommendation 12, at 16 (Feb. 2012) available at http://www.fatf-gafi.org/media/fatf/documents/recommendations/pdfs/FATF_Recommendations.pdf.

11 Supra note 8, at 18-19, 27-29 (Illustrating discrepancies between international PEPs standards in defining to what extent the family members and close associates of PEPs, military officers, judiciary and diplomats should be categorized as PEPs).
} 
Such coordination along both dimensions would eliminate key factors normally influencing financial institutions' to exercise their business judgement-such as the tremendous compliance costs and difficulties in identifying PEPs as well as the increased risk of serious fines for compliance failures - thereby negatively affecting many innocent PEPs while maximizing corruption deterrence.

Yet, the discussions needed to build on this cornerstone by pursuing coordination along the second dimension have been lacking in academia. ${ }^{12}$ This paper offers some policy recommendations on this timely topic.

Part II clarifies the rationale behind the global AML/PEP regulations imposing a higher level of a duty to report on financial institutions specifically against corruption. In addition, it assesses coordination on the substantive definition of PEPs provided in different types of global AML/PEP standards. Based on this trans-border coordination along the first dimension, Part III develops the argument for coordination along the second dimension between public government authorities and private financial institutions. As current global AML/PEP regulations require only financial institutions to share their information with public authorities, this paper focuses on incorporation of sharing requisite governmental information with private financial institutions into global AML/PEP regulation. Considering the

\footnotetext{
12 Few academic scholarships deal with the problems of PEP regulations. However, much of the debates in the academic scholarships study problems of PEP regulations in a broader context lacking a profound analysis on PEP regulations. See Richard K. Gordon, Losing the War Against Dirty Money: Rethinking Global Standards on Preventing Money Laundering and Terrorism Financing, 21 DUKE J. COMP. \& INT'L L. 503, 525 (2011); Richard K. Gordon, Trysts or Terrorists? Financial Institutions and the Search for Bad Guys, 43 WAKE FOREST L. REV. 699, 737 (2008). Even a literature specifically focusing on PEP regulations tends to repeat the argument - variance among approaches between international standard setters - made by the reports of standard making bodies or their affiliates. See Paul L. Lee, A Renewed Focus on Foreign Corruption and Politically Exposed Persons, 127 BANKING L.J. 813, 820 (2010). Professor Matthew Stephenson navigated the possibility of a Public Registry of PEPs by contradicting the comment of David Lewis, the Executive Secretary of FATF, who disregarded such possibility. However, it was rather to open a discussion in an informal setting. Matthew Stephenson, Should There Be a Public Registry of Politically Exposed Persons?, THE GLOBAL ANTICORRUPTION BLOG (June 7, 2016), https://globalanticorruptionblog.com/2016/06/07/should-there-be-apublic-registry-of-politically-exposed-persons/ (last visited Mar. 25, 2017).
} 
characteristics of PEPs information, it illustrates why and how this coordination between public authorities and private financial institutions at the global level should be made.

\section{TRANS-BORDER COORDINATION: HARMONIZATION OF GLOBAL AML/PEP REGULATIONS}

\section{A. Corruption, Money Laundering and Global Administrative Law}

Defining corruption, which is a reflection of social phenomena, organizational structure and personal behavior, is difficult. There have been efforts by scholars to provide definitions of corruption in a broad sense. According to the definition by Nye, corruption is a "behavior which deviates from the formal duties of a public role because of privateregarding ... pecuniary or status gains." ${ }^{\text {13 }}$ Klaveren defines corruption as a civil servant using its office as an income maximizing unit, ${ }^{14}$ and Friedrich defines corruption as "where a power holder . . . take[s] actions which favour whoever provides the rewards [not legally provided for]." $" 15$

Various scholars have defined corruption in their own ways, but many of those definitions have a common denominator, which is "private economic gain." Thus, as in many other profit-generating crimes, money laundering is an essential part of corruption-domestic or foreign - because its proceeds are to be hidden from detection of law enforcement authorities. $^{16}$

\footnotetext{
13 Joseph S. Nye, Corruption and Political Development: A Cost-Benefit Analysis, 61 Am. PoL. SCI. REv. 417, 419 (1967).

${ }^{14}$ Acob Van Klaveren, The Concept of Corruption, in Political CoRruPtion : A HANDBOoK, at 25-26 (A. J. Heidenheimer et al. ed, 1989).

${ }^{15}$ C. J. Friedrich, Political Pathology, 37:1 THE POL. Q. 70, 74 (1966).

16 See generally D. Chaikin \& J. Sharman, CORRUPTION AND MONEY LAUNDERING: A SYMBIOTIC

RELATIONSHIP (2009).
} 
Due to globalization and rapidly developing technologies, financial instruments are moving rapidly across borders in huge volumes. Although the exchange of clean money between people, institutions and corporations has tremendously increased for many legitimate purposes, it has also provided criminals with opportunities to shop for favorable jurisdictions. This, in turn, has led to deterioration in the detection rate for crime, which is an essential component of crime deterrence. ${ }^{17}$

Many corruption cases have demonstrated that corrupted officials, whether from developing ${ }^{18}$ or developed countries, ${ }^{19}$ are laundering illegally gotten gains in diverse ways using financial institutions and other intermediaries in both domestic and foreign jurisdictions to hide their sources. The negative effect of money laundering and related predicate crimes, in this case corruption, extends beyond one state. The International Monetary Fund (IMF) explains that it could undermine the stability of a country's financial system or its broader economy in a number of ways and may have adverse spillover effects on global stability; it gives the examples of Afghanistan, Antigua and Barbuda, the Dominican Republic and Greece. ${ }^{20}$

Thus, corruption that is supported by money laundering in this integrated global economy has developed into a global problem requiring strong trans-border regulatory

\footnotetext{
17 Jennifer Arlen \& Reinier Kraakman, Controlling Corporate Misconduct: An Analysis of Corporate Liability Regimes, 72 N.Y.U. L. REV. 687, 779 n.22 (1997) ("[I]ndividuals . . . are more deterred by a high probability of a relatively low sanction than a low probability of a very high sanction.") (citing JAMES Q. WILSON \& RICHARD J. HERRNSTEIN, CRIME \& HUMAN NATURE 397-401 (1985)).

${ }^{18}$ FATF, Specific Risk Factors in the Laundering of Proceeds of Corruption, at 14, 15 (July 2012) available at http://www.fatfgafi.org/media/fatf/documents/reports/Specific\%20Risk\%20Factors\%20in\%20the\%20Laundering\%20of\%20Pr oceeds $\% 20$ of $\% 20$ Corruption.pdf. (providing corruption cases of James Ibori, a former governor of Delta State in Nigeria and Lazarenko, a former prime minister of Ukraine).

19 See U.S. v. Randall Harold Cunningham aka Randy "Duke" Cunningham, no. 05cr2137-LAB (S.D.Cal, Nov. 28, 2005), available at http://fl1.findlaw.com/news.findlaw.com/wp/docs/crim/uscnnghm112805cinf.pdf.

${ }^{20}$ International Monetary Fund, Anti-Money Laundering and Combating the Financing of Terrorism inclusion in surveillance and financail stability assessments-Guidance Note, at 5-6 (Dec. 14, 2012), avialble at http://www.imf.org/external/np/pp/eng/2012/121412a.pdf.
} 
coordination, which is being shaped by a "growing body of Global Administrative Law [(GAL)]."21 After the Cold War, academic and policy debates have centered around corruption in developing countries, and the typical solution was mostly pursued "in the context of [a domestic] governance framework." 22 This holistic governance approach focused on the "nature of functioning of a state's institutional and structural arrangements, decision-making processes, policy formulation, implementation capacity, information flows, effectiveness of leadership, and the nature of the relationship between rulers and the ruled." 23 However, to effectively tackle the contemporary problem of corruption, growing interdependence means that global governance can only be attained by strong trans-border regulatory coordination.

From the perspective of corruption deterrence, the next section focuses on how PEP regulation as a part of global AML regulation has evolved and whether it has achieved the required strong regulatory coordination at the global level.

\section{B. Trans-border Coordination of Global AML/PEP Regulations}

\section{i. PEP Regulation: a Special AML Tool for Corruption Deterrence}

The manifest relationship between corruption and money laundering across diverse jurisdictions, as explained above, shows that global AML regulation would be an effective way of controlling corruption. To prevent criminals from easily evading detection by law enforcement authorities, financial institutions are required to assist law enforcement authorities by reporting suspicious activities under global AML regulation. However, this still does not

\footnotetext{
21 Benedict Kingsbury \& Nico Krisch \& Richard B.Stewart, The emergence of global administrative law, 68 L. \& CONTEMP. PROBS. 15 (2005).

22 Aland oding \& Stephen Riley, Corruption and Ant-corruption Strategies: Issues and case studies from Developing Countries, in CORRUPTION \& INTEGRITY IMPROVEMENT INITIATIVE IN DEVELOPING COUNTRIES, at 45, 47 (United Nations Pubns, 1998).

23 Id. at 46.
} 
provide an explanation as to why corruption requires special attention in relation to global AML regulation when corruption is just one of many predicate crimes of money laundering.

Specifically targeting only corruption, global AML regulation embraced PEP regulation to impose a higher level of due diligence duty, EDD, on financial institutions against transactions made with PEPs. As AML has to go through a risk-based analysis, EDD could actually be triggered by many other risk factors: the client's business industry or country of origin, destination or origin country of transaction, etc. However, PEP is the only factor which AML regulations explicitly name for financial institutions to consider in applying EDD and which is adopted to deter one specific crime, corruption. Though equally important as PEP, most of the risk factors are not explicitly named by AML regulations as an EDD triggering factor. While AML regulations manifestly require the transaction made with a correspondent account for certain foreign banks ${ }^{24}$ to be under EDD, like PEP, it is not to deter any specific crime.

This distinct treatment of corruption from the AML perspective is justified and underpinned by the seriousness of corruption and the low corruption detection rate. The serious corrosive effect of corruption to the global community across diverse sectors, not limited to the economy, is widely acknowledged. The negative effect of corruption on economic development has been extensively proven in so far as corruption reduces a country's attractiveness for making investments, capital accumulation, capital inflows, productivity of capital, and economic welfare all of which are interrelated. ${ }^{25}$ In addition to its negative effect on economic development, corruption "prevents people [particularly the most vulnerable and marginalized people] from fulfilling their political, civil, social, cultural and economic

\footnotetext{
2431 CFR 1010.610 (b).

25 Johann Graf Lambsdorff, Corruption in Empirical Research - A Review, TRANSPARENCY INTERNATIONAL (November 1999) available at http://www1.worldbank.org/publicsector/anticorrupt/d2ws1_jglambsdorff.pdf.
} 
rights." ${ }^{26}$ Such harms caused by corruption have been recognized by the international society as illustrated in the message of the former Secretary General of the United Nations, Ban Kimoon, that "[c]orruption destroys opportunities and creates rampant inequalities and undermines human rights and good governance, stifles economic growth and distorts markets." 27

While society as a whole is a victim of corruption, there is no identifiable victim to report the crime of corruption. Victim reporting is the main source of crime detection. However, most acts of bribery, one of the most common criminal acts of corruption, which is many times interchangeably used with corruption, ${ }^{28}$ have no identifiable victim. For instance, a car driver paying a bribe to a police officer to avoid a traffic offense does not generate any direct victim. Even in those cases where potential or actual individual victims of bribery exist, the victims might fail to recognize the harm caused by the bribery to them. For instance, when a company has paid a bribe to a government officer to win a government contract, it is difficult for other bidding competitors to know about the existence of bribery and the chain of causation between the bribe and the winning of the contract. The same is true, though to a lesser extent, for other types of criminal acts of corruption, such as abuse of authority or embezzlement.

Thus, to complement the lower detection rate for corruption, which undoubtedly causes serious damage to our society, a higher level of AML duty of financial institutions against PEPs is justified. In addition, the recent global trend of active and strong enforcement actions against corruption makes it particularly essential, ${ }^{29}$ as the willing corrupted officers

\footnotetext{
26 International Council on Human Rights Policy, Corruption and Human Rights: Making the Connection, at 23 (2009) available at http://www.ichrp.org/files/reports/40/131_web.pdf.

27 Press Release, U.N. Secretary-General, In Message For International Anti-Corruption Day, Says Prevention Critical To Securing Rule of Law, U.N. Press Release SG/SM/14703 (Dec. 6, 2012), http://www.un.org/News/Press/docs/2012/sgsm14703.doc.htm.

28 Supra note 26, at 17.

29 See FRESHFIELDS BRUCKHAUS DERINGER, Anti-bribery and corruption: global enforcement and legislative developments 2017, at 2 (2017), available at
} 
and bribers are expected to put more efforts into laundering the illicit money to avoid such law enforcement actions. Where offenders are struggling to avoid detection and victims to report are largely absent, the higher AML duty against PEPs imposed on financial institutions as third party witnesses of corruption is imperative.

\section{ii. Possibilities and Limitations of Global AML/PEP Regulations for Trans-}

\section{border Coordination}

Traditionally, administrative measures have been adopted at the domestic level solely by a government. However, as crimes are globalized, these administrative regulations, including AML/PEP regulation adopted as an instrument to deter crimes are increasingly made at the international level by various international actors to remove legal loopholes through strong trans-border coordination: thus, there has been a process of harmonization of domestic regulations.

To deter crimes of money laundering and corruption moving freely across borders, a broad range of international actors ${ }^{30}$ have came up with their own forms of global AML/PEP standards. Not only government agencies vested with treaty making authority, normally a ministry of foreign affairs, but also pure domestic administrative agencies and private financial institutions have become constantly involved with one another.

However, trans-border coordination of the AML/PEP regulations is not an easy task due to discrepancies between two main global standards: UNCAC and FAFT recommendations. In 2003, the UNCAC introduced the concept in relation to PEPs that "each State Party . . .

http://www.freshfields.com/uploadedFiles/SiteWide/Campaigns/GI/content/GI\%20ABC\%20guide\%202016.PD F; TRACE INTERNATIONAL REPORT, Global Enforcement Report 2016, at 8 (2017), available at https://traceinternational.org/Uploads/PublicationFiles/TRACEGlobalEnforcementReport2016_1.pdf.

30 See I. p.1. 
[shall] require banks ... to conduct enhanced scrutiny of accounts sought or maintained by or on behalf of individuals who are, or have been, entrusted with prominent public functions and their family members and associates." $31 \quad$ The FATF soon followed the UNCAC by adopting a PEP standard in its Recommendation 6 of the FATF's 40 Recommendations, which required financial institutions to exercise enhanced due diligence against PEPs, defined as "individuals who are or have been entrusted with prominent public functions in a foreign country . . .."32

In addition to other still remaining discrepancies not explored in this paper, ${ }^{33}$ the main discrepancy between UNCAC and FATF recommendations was whether to include domestic PEPs within the PEP definition. While UNCAC did not make a distinction between foreign and domestic PEPs, the FATF recommendations clearly limited the PEP regulation to foreign PEPs.

These discrepancies led to a low compliance rate with global PEP regulation ${ }^{34}$ thus lowering the level of trans-border coordination. As correctly pointed out by the World Bank, "the current variations among approaches serve as both a good excuse not to act and are seen by some as a real impediment to the development and implementation of effective PEPs controls." 35 As illustrated by the abovementioned corruption cases, these gaps are easily abused by corrupted officers.

However, in February 2012, this main substantive discrepancy was reconciled by the inclusion of domestic PEPs into the FATF Recommendations. The FATF revised its Recommendations to require financial institutions to "determine whether a customer or

\footnotetext{
31 Supra note 2 (emphasis added).

32 Supra note 3, at 17 (emphasis added).

33 Supra note 11.

34 Supra note 8.

35 Supra note 9.
} 
beneficial owner is a domestic PEP ... [and] to apply the [EDD] measures ... [to such persons]." 36

That reconciliation is the focus of this research. It helps international society to consider the reality instead of the "myth" that foreign PEPs are risky but domestic PEPs are safe. ${ }^{37}$ More importantly, as domestic PEP lists are information possessed by governments by their very nature, since they are mainly about government employees, the inclusion of domestic PEPs into FATF Recommendations provides a foundation to incorporate the public-private coordination along the second dimension-forming two-way information sharing by providing domestic PEP lists to financial institutions who have a duty to report suspicious activities to public authorities_-into global AML/PEP regulation.

\section{PUBLIC-PRIVATE COORDINATION: SHARING OF GOVERNMENTAL PEP LISTS WITH FINANCIAL INSTITUTIONS}

Global AML/PEP regulations require a sharing of information owned by financial institutions with public authorities by mandating reporting of suspicious activities to public authorities. This is one-way coordination between the public and private sectors.

To achieve two-way coordination, this paper focuses on the other means for coordination — sharing requisite governmental information with financial institutions — which is currently lacking. This section will study why and how this two-way coordination between public authorities and private financial institutions should be incorporated into global AML/PEP regulation. To do so, this paper suggests specific procedural and institutional

\footnotetext{
36 Supra note 10.

37 Organization for Economic Cooperation and Development [OECD], ADB/OECD Anti-Corruption Initiative for Asia and the Pacific, at 2 (Sept. 9, 2009), available at http://www.oecd.org/site/adboecdanticorruptioninitiative/meetingsandconferences/44442190.pdf.
} 
recommendations to minimize the collateral damage to innocent PEPs while securing maximum corruption deterrence.

\section{A. Why Public-Private Coordination under Global AML/PEP regulation?}

One possible answer to the above question is that public-private coordination could prevent negative impacts on innocent PEPs by decreasing the compliance cost of financial institutions and increasing the completeness of PEP list. Circling back to the introduction, the bank account of Mr. Ocampo, Columbia's former finance minister and former World Bank presidential nominee, was terminated by JPMorgan merely because of his status as a PEP. Not only Mr. Ocampo but many others have been similarly categorized as PEPs whose accounts, (totalling approximately 3,500) were affected by the ban from JPMorgan. ${ }^{38}$ Mr. Ocampo and many others are not criminals, but in line with his reaction to JPMorgan's actions, they were also unfairly treated like criminals simply because of their status as PEPs. ${ }^{39}$ It was not just JPMorgan, but also HSBC that have taken similar paths for years against foreign officials including diplomats in the US. ${ }^{40}$

This termination of the relationship with PEPs is not intended but actually discouraged by PEP regulations. For instance, the UNCAC clarified that "[s]uch enhanced scrutiny . . . should not be so construed as to discourage or prohibit financial institutions from doing business with any legitimate customer." 41 The FATF also emphasized that PEP regulations are "preventive (not criminal) in nature, and should not be interpreted as stigmatizing PEPs as such being involved in criminal activity. Refusing a business relationship with a PEP simply

\footnotetext{
38 Supra note 1.

39 Id.

$40 \mathrm{Id}$.

41 Supra note 2.
} 
based on the determination that the client is a PEP is contrary to the letter and spirit of Recommendation 12." 42

However, due to the tremendous compliance costs incurred with the identification and monitoring of PEPs, coupled with an increased risk of serious fines for compliance failures, financial institutions have voluntarily made such business judgements, thereby negatively affecting innocent PEPs, particularly foreign PEPs, or even false-PEPs wrongly listed as PEPs. ${ }^{43}$

To identify PEPs, monitor and update the continuously changing PEP information, each financial institution bears expensive personnel costs to carry out their in-house PEP analysis. ${ }^{44}$ Regarding the category of domestic PEPs, which has been recently added to the FATF recommendations, it would be relatively easy and less expensive for the domestic financial institutions to gain the relevant information since they know the language, culture, and governmental system, etc. However, foreign PEPs present a different challenge. Identification and monitoring of foreign PEPs is a daunting task for the employees of financial institutions as the information needed to monitor them encompasses all foreign jurisdictions, often with unfamiliar language, culture, and governmental systems, etc.

Thus, some financial institutions instead rely on a PEP database service of Commercial Data Providers (CDP), such as World-Check, World Compliance, Accuity, etc., which is

\footnotetext{
42 FATF, FATF Guicance Politically Exposed Persons(Recommendation 12 and 22), at 3 (2013), available at http://www.fatf-gafi.org/media/fatf/documents/recommendations/Guidance-PEP-Rec12-22.pdf.

43 See David Artingstall, Nick Dove, John Howell \& Michael Levi, Drivers \& Impacts of Derisking, at 7, 11 (February 2016) https://www.fca.org.uk/publication/research/drivers-impacts-of-derisking.pdf.

${ }^{44}$ See Rupert de Ruig, The New Step by Step Approach to Client Screening, Dow Jones WATCHLIST, 3 (2008) (explaining people cost for financial institutions to carry out general watch-list client screening using vendor services), http://factiva.com/en/cp/collateral/files/djwl_whitepaper_en.pdf. The people cost will be much higher for financial institutions not using vendor services, as additional human resources are required to carry out the services what they buy from the vendors.
} 
regarded as costly. ${ }^{45}$ Though the fee may vary between CDPs, use of such services imposes a huge financial burden on financial institutions, as properly expressed by the World Council of Credit Unions in its letter to the Basel Committee expressing its opposition to the mandatory use of vendor-created PEP lists implied by the Basel Committee's "Sound management of risks related to money laundering and financing of terrorism" consultative document. ${ }^{46}$

Furthermore, reports from the World $\mathrm{Bank}^{47}$ and the $\mathrm{FATF}^{48}$ recommend financial institutions to maintain in-house analysis even when they are using CDP databases. Accordingly, overall AML/PEP compliance costs for the financial industry would be massive.

However, this high-cost endeavor of financial institutions to identify and monitor PEPs is necessarily incomplete because it is limited to the information publicly available or provided by the clients. ${ }^{49}$ In particular, and for the same reasons that the cost of PEP identification and monitoring is higher for foreign PEP lists than domestic PEP lists, the degree of incompleteness concerning the PEP identification and monitoring would be higher for foreign PEP lists than for the domestic PEP lists. This has been properly recognized by the US Senate Subcommittee investigation on the corruption case of Omar Bongo, President of Gabon, wherein it was observed, "[s]ome vendors relied on by U.S. financial institutions to screen clients for PEPs used incomplete and unreliable PEP lists."

\footnotetext{
45 Supra note 8, at 46. ("the entire package of services - the database, software, and staff to review the hitscan became quite a costly venture.”).

46 See World CouncIL OF CREDIT UnION, Re: Consultative Document: Sound management of risks related to money laundering and financing of terrorism (bcbs 252), at 2, (Sept. 27, 2013), available at https://www.woccu.org/documents/WOCCU_Basel_AML.

47 Supra note 8, at 46.

48 Supra note 42 , at 17.

49 Supra note 8 , at 45-46.

50 S. Permanent Subcomm. On Investigations Comm. on Homeland SEC. AND Governmental AFFAIRS, Keeping Foreign Corruption Out of the United States: Four Cases Histories, at 3 (2010) available at https://www.hsgac.senate.gov/download/report-psi-staff-report-keeping-foreign-corruption-out-of-the-unitedstates-four-case-histories.
} 
Accordingly, even with their expensive AML/PEP compliance efforts, financial institutions are exposed to an increasing risk of serious fines for AML/PEP compliance failures. Though the enforcement action differs by jurisdiction, in the case of the US whose enforcement action as a center of international banking indeed affects not only US financial institutions but also non-US financial institutions operating in the US, the regulators have aggressively enforced AML measures for non-compliance. ${ }^{51}$ Moreover, the penalties for non-compliance by financial institutions have risen sharply since late $2009 .{ }^{52}$

The risk of serious fines together with the incompleteness of PEP identification, particularly regarding foreign PEPs, motivates financial institutions to act defensively by giving the benefit of the doubt and overly broadening the PEPs list. With the active and strong enforcement of AML breaches, the US Financial Crimes Enforcement Network (FinCEN) has been concerned with defensive actions of financial institutions by reporting low quality SAR. ${ }^{53}$ A similar defensive action could be manifested in PEP listings, thus increasing the risk of even false-PEPs being wrongly listed as PEPs.

Despite the abovementioned concerns, review systems to prevent overly broadened PEP lists have not been established in global AML/PEP regulations. Considering the negative effects on the persons listed, particularly false-PEPs, law may be needed to regulate financial institutions to prevent such harm. The law may not direct financial institution's business judgement whether to maintain business with PEPs or not, but the law may dictate procedures that financial institutions should follow in making PEP lists to maintain accountability and to protect false-hit clients. This is even more important when no public scrutiny is available, since

\footnotetext{
51 Sharon Brown-Hruska, Developments in Bank Secrecy Act and Anti-Money Laundering Enforcement and Litigation, NERA ECONOMIC CONSULTING, at 2 (June 2016) available at http://www.nera.com/content/dam/nera/publications/2016/PUB_Developments_BSA_AML_Lit-06.16.pdf. $52 I d$, at 7-8.

$53 \mathrm{Id}$, at 10.
} 
financial institutions and CDPs are reluctant to provide information on the criteria, indicators, or the process of establishing PEP lists to the public as it is a protected business secret. Nevertheless, no state certifies or authorizes the PEP list or PEP listing procedures of financial institutions and CDPs. Financial institutions are not required to give notice to the clients who are registered as PEPs; to give reasons why the customers are registered as PEP. Even clients mistakenly listed as PEPs are not given an opportunity to ask financial institutions for a review or delisting.

The overly broadened PEP identification only makes a vicious circle of increasing the already expensive monitoring cost of financial institutions. It is unable to improve the inherent incompleteness of PEP monitoring, thus it fails to curtail the risk of serious fines for noncompliance. This combination of high cost of PEP monitoring and risk of serious fines has led financial institutions, even big ones such as JPMorgan, to voluntarily terminate business with individuals identified as PEPs, particularly foreign PEPs, who are mostly innocent or wrongly identified as PEPs.

Public-private coordination incorporated into global AML/PEP regulation could prevent such negative impacts on innocent PEPs including the false-PEPs, as it would decrease the compliance costs of financial institutions and increase the completeness and integrity of PEP lists. For public-private coordination, governments would share domestic PEP lists with financial institutions that have a duty to report suspicious activities to a government. Domestic PEP list-making by government would cost a lot less, perhaps almost nothing, as domestic PEPs are employees of the government. Needless to say, the lists would be comprehensive and complete.

\section{B. A Global Regulatory AML/PEP Body for Public-Private Coordination}




\section{i. A Framework of Global Public-Private Coordination: Mutual Recognition of Domestic PEP Lists}

The sharing of domestic PEP lists made by governments is not limited to sharing with domestic financial institutions, but also with other foreign financial institutions. This is not to say that governments should come up with a list of both domestic and foreign PEPs and share it with domestic financial institutions. When it comes to foreign PEPs, obtaining a comprehensive list would be a daunting task for governments. Incorporating a duty on governments to issue a list of foreign PEPs to share with their domestic financial institutions into the global AML/PEP regulation is neither practical nor reasonable for the rationales discussed below.

First and foremost, a government does not possess the requisite information to issue a foreign PEPs list. As foreign PEPs are the employees of foreign governments, without sharing by foreign governments of their own domestic PEPs list-which is what I suggest-a government needs to rely mainly on public information just as financial institutions do. In addition, corruption has a cultural aspect, which sometimes may not be easily understood by foreigners, and each government system is different from one another. Thus, it is difficult for a government, as it is for financial institutions, to know in which parts of foreign governments corruption exists or in which sectors it is most prevalent and who has the authority which can be most readily abused for personal gain.

Secondly, although a government may have better sources of information on foreign PEPs through its agencies cooperating with foreign governments or collecting foreign intelligence than financial institutions that are solely relying on publicly available information, such gathering of information-more specifically, identifiable information —on foreign senior 
officers would still be incomplete, financially costly and sometimes politically risky. More importantly, the information secretly gathered would remain confidential, which undermines the fundamental ground for public-private coordination.

Accordingly, this paper suggests each government should establish its own domestic PEP list and share it with domestic and foreign financial institutions that are in need of such information to carry out their AML/PEP duties to report suspicions of corruption under the global AML/PEP regulations. With the inclusion of domestic PEPs into FATF recommendations, there seem to be stronger justifications for such public-private coordination.

For this purpose, mutual recognition should be the basic framework of this global public-private coordination as it provides the principles governing the recognition of foreign laws, regulations, standards and certification procedures among states. ${ }^{54}$ The especially important aspect of mutual recognition is that it would allow us to live with our differences ${ }^{55}$ but within the limits set by the international standards; this could provide great benefit for global AML/PEP regulation, as corruption is to some extent culturally specific to each society. This mutual recognition would be operationalized in a manner whereby the domestic PEP list created by each government would be recognized by foreign financial institutions, and obviously by domestic financial institutions as well.

\section{ii. Caveats on a Global AML/PEP Regulatory Body}

For successful implementation of global public-private coordination based on mutual recognition of domestic PEPs lists, the global AML/PEP regulatory body, whether it is the UN

\footnotetext{
${ }^{54}$ Kalypso Nicolaidis \& Gregory Shaffer, Transnational Mutual Recognition Regimes: Governance Without Global Government, L. \& CONTEMP. PROBS. 263, 268 (2005).

$55 \quad I d$. at 269.
} 
or the FATF, should respect three essential values: accountability of states providing the list to foreign states/financial institutions, accountability to the listed domestic PEPs and protection of the privacy of the PEPs. In order for each of these three values to be realized, the global AML/PEP regulatory body would need to introduce certain institutional and procedural measures into its regulations. Neglecting these values and failure to embrace the required institutional and procedural measures would result in the global AML/PEP regulatory body's failure to attain legitimacy and effectiveness. Each of the three key values is discussed in turn below.

\section{a. Accountability to Other States}

The global public-private coordination suggested in this paper is premised on the assumption that all states will provide the complete, authentic and reliable information of domestic PEPs without cheating others receiving the information. To see whether and howunder which institutional and procedural manners - states would be motivated to do so, it is necessary to first consider the characteristics of the information being shared by states.

Mainly, the domestic PEP list consists of sensitive information in relation to which it is difficult to establish trust - the essential component of information sharing ${ }^{56}$ - between states: states providing the information and states receiving the information. This lack of trust compromises the completeness and authenticity of the shared information.

The domestic PEP list to be shared generally should include identifiable information about the senior government officials of each state. Though there exists a lack of harmonization

\footnotetext{
56 See Panteli \& Sockalingam, Trust and conflict within virtual inter-organizational alliances: a framework for facilitating knowledge sharing, 39 DECISION SUPPORT SYS. 599 (2005); Dirks \& Ferrin, The Role of Trust in Organizational Settings, 12 ORG. SCI., 450 (2001); Dale E. Zand, Trust and Managerial Problem Solving, 17 ADMIN. SCI. QUARTERLY 229 (1972).
} 
in the PEP definitions of global standards, the common core of PEPs, which are agreed upon even among diverse definitions, is that PEPs are the senior government officials. The PEP list is the identifiable information-names, positions, dates of birth, identification numbers and photos - of those individuals so that bank tellers could use the information to discern whether the client is a PEP or not.

As national interest shapes behaviors of states competing with each other, ${ }^{57}$ states are not likely to voluntarily and unilaterally share the complete, authentic and reliable information on their senior officers, particularly but not limited to, in the field of national security - military or intelligence-, with other states. The states providing the domestic PEP list would be anxious about abuse of the shared information by the foreign states receiving the information against the interest of the providing states.

Then, the question arises, will there be a formalized agreement to impose a duty on states to share domestic PEPs lists and will this be incorporated into global AML/PEP regulations?

As deterrence of corruption through strong AML is a public good ${ }^{58}$ which benefits every constituent of this interconnected international society, ${ }^{59}$ states are incentivized to mutually share the requisite PEP information. However, as long as the risk of harm to their national interests by sharing exists, states will enter into such agreements only when the incentives eclipse such risk.

\footnotetext{
57 Anne L. Herbert, Cooperation in International Relations: A Comparison of Keohane, Haas and Franck, 14 BERKELEY J. INT'L LAW. 222, 226 (1996).

58 Martin Brookes \& Zaki Wahhaj, Global Public Goods Arguments for Collective Action, INTERNATIONAL COUNCIL ON HUMAN RIGHTS POLICY, at 1 (2001), http://www.ichrp.org/files/papers/94/108__Global_Public_Goods_-_Arguments_for_Collective_Action_Brookes_Martin_Wahhaj_Zaki_2001.pdf. 59 See II.A.\&B.1., pp.6- 9 .
} 
Furthermore, even when formalized information sharing is attained through the global AML/PEP regulatory body, upholding trust between states is not guaranteed. States may freely breach such duty by cheating and withholding some information to pursue their own national interests, ${ }^{60}$ as a supra-national government with law enforcement authority is lacking from international society. However, pursuing state self-interest would not be the only reason for such non-compliance. As domestic political interest obviates the enforcement of international law at the domestic level, ${ }^{61}$ there exists the risk of a ruling party of the state providing the domestic PEP list and abusing its power to prepare the list unfairly and partially to suppress opposition parties. This concern about possible cheating reinforces the motivation of states not to enter into a formalized information sharing agreement.

Accordingly, for the formalized information sharing agreement to be operationalized, institutional and procedural measures would have to be adopted to reduce the concerns of states: the risk of harm to their national interests and potential cheating by other states.

First of all, to prevent states from cheating and to encourage compliance, it is essential for the global AML/PEP regulatory body to supervise state practices with "an auditing device that checks at an appropriate frequency the integrity of the data submitted by the participants and penalizes by an appropriate amount the cheating behaviors." 62

To check the domestic PEP list prepared by each state, the global AML/PEP regulatory body needs a centralized repository of international PEP lists managed by itself rather than

\footnotetext{
60 Jack L. Goldsmith \& Eric A. Posner, The Limits of International Law, THE AMERICAN ENTERPRISE INSTITUTE FOR PUBLIC POLICY RESEARCH, at 3 (2005), available at http://www.angelfire.com/jazz/sugimoto/law.pdf.

61 See generally Jide Nzelibe, Strategic Globalization: International Law as an Extension of Domestic Political Conflict, 105 Nw. U. L. REV. 635 (2011).

62 Rakesh Agrawal \& Evimaria Terzi, On Honesty in Sovereign Information Sharing, in ADVANCES IN DATABASE TECHNOLOGY - EDBT 2006 240, 255 (2006) (emphasis added).
} 
decentralized international PEP data centers managed by each state. The former is where states proactively provide and simultaneously update the data of domestic PEP lists to the international PEPs data center to which access by all financial institutions is allowed. The latter is where each state establishes its own international PEPs data center utilizing the domestic PEPs data shared by foreign states and allows access by its domestic financial institutions.

Checks by the global AML/PEP regulatory body under the decentralized international PEP data centers, apart from its apparent high management cost from the perspective of an international society, ${ }^{63}$ are less likely to overcome the problems of cheating by, and distrust between, states. In contrast to the proposed centralized international PEP data center where the information would be audited by the global AML/PEP regulatory body and identical information would be accessed by financial institutions, a global AML/PEP regulatory body under the decentralized international PEP data centers has to rely on the reactive information provided by states in response to periodic audit requests. This leaves room for states to cheat by providing the information detached from the actual information accessed by financial institutions. To prevent such cheating, the verification of the integrity of the reactive information requires on-site inspections. However, on-site inspections are not only expensive, but also conditioned upon active cooperation from states, which is not guaranteed.

To appropriately penalize non-compliance by states, the global AML/PEP regulatory body would require authority to impose FATF-style soft sanctions. As the stake involved with global AML/PEP regulation is small compared to international laws on war crimes or territorial limits ${ }^{64}$ it does not necessarily need to be a military or economic sanction, but a soft sanction. A good example would be mutual evaluation and the 'naming and shaming' utilized by the

\footnotetext{
63 Infra note $97,98$.

64 See Andrew T. Guzman, A Compliance Based Theory of International Law, 90:6 CAL. L. REV. 1823,18601871 (2002).
} 
FATF, one of the global AML/PEP regulatory bodies, to make member states (and sometimes even non-member states) comply with its recommendations. ${ }^{65}$

Secondly, to eliminate, or at least to minimize the risk of harm to their national interests by sharing, it is essential for the centralized international PEP data center managed by the global AML/PEP regulatory body to remove the unnecessary involvement of states. Financial institutions would be allowed to directly, not indirectly through their own domestic states, access and query the international PEP data center. As it is the financial institutions, not states, which have the responsibility to detect suspicious corruption by utilizing the PEP list, there is no reason for the PEP list to be indirectly processed through the states to reach the financial institutions. This will address the concerns of states providing the domestic PEP lists about possible abuse of the shared information by the receiving states. Supported by the supervisory role of the global AML/PEP regulatory body, the international PEP data center will help to achieve this objective by preventing states from cheating, such as coercing their domestic financial institutions to provide the PEP information shared by foreign states.

\section{b. Accountability to the Listed PEPs}

The second value that must be respected by the proposed AML/PEP regulatory body is accountability to the listed PEPs. As illustrated in the previous section, all current privately collated PEP lists (whether they be created in-house or sourced commercially from CDPs) are in need of procedural measures to secure accountability to the innocently listed PEPs, particularly the false-PEPs. ${ }^{66}$ This is due to the high possibility of financial institutions overly broadening their lists of PEPs and treating them as criminals. The public-private coordination

\footnotetext{
65 See FATF, High-risk and Non-cooperative Jurisdictions, http://www.fatf-gafi.org/publications/highriskandnon-cooperativejurisdictions/more/more-on-high-risk-and-non-cooperativejurisdictions.html?hf=10\&b=0\&s=desc(fatf_releasedate) (last visited Mar. 28, 2017). 66 See III. A, pp. 16-17.
} 
proposed in this research would largely eliminate the roots of such possibility by decreasing compliance costs and enhancing the completeness of the PEP lists. However, the suggested public-private coordination wherein states establish a list of domestic PEPs and share those with domestic and foreign financial institutions will still be required to embrace procedural measures to secure accountability to the listed PEPs.

Accountability to the listed PEPs is required as a matter of principle in administrative law under the suggested public-private coordination, unlike the former argument that accountability to the listed PEPs was desirable as a matter of policy to protect wrongly listed PEPs under the privately created PEP lists. ${ }^{67}$

As a part of domestic governance, ${ }^{68}$ discretionary decisions of administrative agencies are required as a principle of administrative law to be made "in a manner that is informed and responsive to the wide range of social and economic interests and values affected by their decision." ${ }^{69}$ Many international organizations such as the World Bank, the IMF, and the OECD have emphasized this principle of accountability is to be upheld by states. ${ }^{70}$

The suggested public-private coordination involves an administrative decision, which requires an exercise of discretion by an administrative agency affecting the rights and interests of the subject of the decision. In deciding whom the domestic PEPs are, the administrative agency needs to exercise its discretion. It is not comparable with the list of, say, sex offenders whose cases have been previously decided and reviewed by the judiciary, ${ }^{71}$ or the list of stolen

\footnotetext{
67 Id.

68 Martin Lodge, Accountability and Transparency in Regulation: Critiques, Doctrines and Instruments, in POLITICS OF REGULATION, 124, 124 (Jacint Jordana and David Levi-Faur, eds., 2004), available at http://regulation.upf.edu/reg-network/papers/lodge2.pdf.

69 Richard B. Stewart, U.S. Administrative Law: A Model for Global Administrative Law?, 68 L. \& CONTEMP. PROBS. 63, 75 (2005).

70 See supra note 68; OECD, OECD Guiding Principles for Regulatory Quality and Performnace, at 5, C(2005)52 and CORR1 (2005), http://www.oecd.org/fr/reformereg/34976533.pdf.

71 See the Sex Offender Registration and Notification Act, 42 U.S. Code $§ \S 16901-16962$ (2006).
} 
passports, which are reported by the victims of crime about objective facts. ${ }^{72}$ Once someone is subjected to the domestic PEP list, the listed PEPs will be under higher surveillance by financial institutions. In addition, though less probable under the public-private coordination than privately made PEP lists, thanks to decreasing compliance costs and increasing completeness of the PEP lists, there still remains a risk of PEPs being disabled from carrying out daily financial activities.

Accordingly, the suggested public-private coordination should respect the accountability principle. More importantly, such accountability measures should be embraced particularly by the global AML/PEP regulations at the international level, not simply by an individual state at the domestic level.

The domestic PEP list issued by a state under the suggested public-private coordination would not simply be a domestic administrative decision, but a global administrative decision with international ramifications. Each state's decisions regarding their domestic PEP lists would be mutually recognized by financial institutions in foreign states. Such decisions would impact not only upon the behaviors of domestic financial institutions, but also on foreign financial institutions to comply with a regulatory AML duty. Therefore, their decisions would affect the rights and interests of the listed PEPs not only domestically, but also internationally.

However, as "the domestic system of political and legal accountability and control ... would apply to purely domestic regulatory measures"73 not to the global regulatory measures, the global AML/PEP regulatory body adopting the proposed public-private coordination would need to employ measures at the international level to secure accountability by respecting the

\footnotetext{
72 DePT. OF STATE, Privacy Impact Assessment: Online Passport Lost \& Stolen System, at 2 (2008), available at https://foia.state.gov/_docs/pia/onlinepassportloststolensystem_oplss.pdf.

73 Supra note 69 , at 69 .
} 
values of "transparency, participation, reasoned decision and decisional review.""74 To do so, and having learned lessons from other similar types of global administrative decisions generally described as a type of GAL, the proposed global AML/PEP regulatory body should incorporate the following: procedural measures requiring states to secure accountability at the domestic level and independent international procedural measures to secure accountability at the international level.

First, embracing the procedural requirements to secure accountability into global AML/PEP regulation is necessary for the global AML/PEP regulatory body to control the different domestic PEP list review procedures of each state. Some global regulatory bodies, to increase accountability and transparency, have begun to adopt administrative law decision making and rule-making procedures ${ }^{75}$ with "which national authorit[ies] should conform in order to assure their compliance and accountability with the international regime."76

Such procedural control by the global regulatory body would be essential to overcome the inherent weakness of mutual recognition as procedural differences in list making by states may easily lead a state to deny recognition of another state's administrative decisions. For instance, the case involving Shengen lists elucidated the importance of procedural control at the international level. In the Hamssaoui and Forabosco cases, the French Conseil d'Etat ruled against the lawfulness of the entry on the SIS made by another Member-state, Germany, based

\footnotetext{
${ }^{74}$ Benedict Kingsbury \& Richard B.Stewart, Legitimacy and Accountability in Global Regulatory Governance: The Emerging Global Administrative Law and the Design and Operation of Administrative Tribunals of International Organizations, in INTERNATIONAL ADMINISTRATIVE TRIBUNALS IN A CHANGING WORLD, 1, 1 (S. Flogaitis ed., 2008).

${ }^{75}$ Supra note 21, at16-17.

${ }^{76} \mathrm{Id}$.
} 
on the fact that Germany failed to provide sufficient information for the claimant regarding the listing of the claimant in the Shengen system. ${ }^{77}$

There are various specific procedures that would need to be embraced and implemented by the global AML/PEP regulation, as illustrated below, and it is worth noting that those procedural measures are feasible and practical only when states make their own domestic PEP lists, as suggested in this paper, but not foreign PEP lists. Procedural safeguards to attain transparent and non-discriminatory administrative decisions, such as participation of opposing party members or civil groups in PEP list making is practical only with domestic PEP lists. In addition, notice to the affected individual is required to make informed and responsive administrative decisions. However, with regards to foreign PEP list making, it is difficult to require states to give notice to all those foreign PEPs from all around the world. From the perspective of listed foreign PEPs, it is suggested that they should receive notice from each state and then petition for a review to each foreign state where they are listed as PEPs. By comparison, when states prepare domestic PEP lists, they are required to give notice respectively only to their domestic personnel. It is also much easier for the listed PEPs to petition for review and hold the decision maker accountable at the domestic level.

However, procedural control by the global regulatory body will fail to overcome the inherent weakness of mutual recognition, when the required accountability procedures are not actually implemented by states. Thus, without monitoring the state's implementation, a global AML/PEP regulatory body will fail to achieve the contractual norm for mutual recognition. ${ }^{78}$ While accountability to other states requires such a supervisory role of a global AML/PEP

\footnotetext{
77 E. Guild, Moving the Borders of Europe, Inaugural Lecture at the University of Nijmegen, at 26 (May 30 , 2001), http://cmr.jur.ru.nl/cmr/docs/oratie.eg.pdf.

78 Supra note 54, at 278.
} 
regulatory body to monitor the substance of the listed PEP, this accountability to the listed PEP demands the same supervisory role against the procedure of PEP list making.

Secondly, the proposed global AML/PEP regulatory body needs to establish its own independent international procedural measures to secure accountability at the international level. In contrast to the other procedures to secure accountability, such as notice and participation, which are to be properly adopted at the domestic level, the petition could be made even, or sometime necessarily, at the international level in addition to the domestic level.

For instance, the UN Security Council (SC) 1267 Committee has been criticized for its lack of accountability in compiling a consolidated list of terrorist individuals and entities to be sanctioned. ${ }^{79}$ The list is prepared and publicized by the SC 1267 committee based on the information supplied by states, and the sanction imposed on such listed individuals and entities is carried out by the private sector who accesses the publicized list. ${ }^{80}$ To be delisted, the individuals requesting delisting have to go through a complicated process both at the domestic and the international level. ${ }^{81}$ Thus, to secure accountability, the committee reformed its procedure by supplying the listed individuals and entities a channel, the Office of Ombudspersons, to make a direct petition and review request for delisting. ${ }^{82}$

The global AML/PEP regulatory body should create an international body, like the Office of the Ombudsperson of the SC 1267 committee, to work as a direct channel of petition

\footnotetext{
79 See Thomas J. Biersteker \& Sue E. Eckert, Strengthening Targeted Sanctions Through Fair and Clear Procedures, WATSON InSTITUTE TARGETED SANCTIONS PROJECT 3, 21-22 (2006) available at http://watsoninstitute.org/pub/Strengthening_Targeted_Sanctions.pdf; Iain Cameron, Protecting Legal Rights: on the (in) security of targeted sanctions, in INTERNATIONAL SANCTIONS: BETWEEN WORDS AND WARS IN THE GLOBAL SYSTEM 189 (Peter Wallensteen \& Carina Staibano eds., 2005).

80 S.C. Res. 1267, U.N. Doc. S/RES/1267 (1999).

81 See E. Alexandra Dosman, For the Record: Designating "Listed Entities" for the Purposes of Terrorist Financing Offenses at Canadian Law, 62 U. TORONTO FAC. OF L. R. 1, 13 (2004).

${ }^{82}$ U.N. Office of the Ombudsperson of the S.C.'s 1267 Comm., Office of the Ombudsperson to the SIL (Da'esh) \& Al-Qaida Sanctions Committee, https://www.un.org/sc/suborg/en/ombudsperson (last visited Dec. 3, 2016).
} 
for review from the listed PEPs. The pubic-private coordination involved in a global AML/PEP regulatory body suggested in this paper is similar to the SC 1267 committee in that the list of individuals provided by states are accessed and used by the private sector in a way to negatively affect the rights and interests of the listed individuals. Thus, to overcome the expected similar accountability barrier, the global AML/PEP regulatory body will be in need of its own Office of the Ombudsperson.

\section{c. Protection of the Privacy Rights of PEPs}

The third value that must be respected is the protection of the PEPs' privacy rights. Under the current AML/PEP regime where financial institutions or CDPs prepare the PEP list, privacy issues are not triggered. This is because the financial institutions or CDPs gather the requisite personal identifiable information (PII) about PEPs from public sources thus rendering the PEP list incomplete in many cases. Financial institutions allow access by their employees to the information in identifying clients as PEPs and higher due diligence is applied in carrying out their AML duties to detect corruption. They do not publicize the information but keep it as a business secret. However, even if they do publicize it, no invasion of privacy will occur, since it is based on already publicly available information.

In contrast, the suggested global AML/PEP regulatory body with pubic-private coordination where the PEP list is shared by states with financial institutions could possibly cause privacy concerns. While the PEP list would be more complete, since it contains information about their own employees, the information possessed and disclosed by states is not limited only to information that is already in the public domain. 
To clarify the position, it is necessary to find out whether the PII about PEP should be protected from disclosure or disclosed to financial institutions for public interest as an exception.

The protection of PII from disclosure is not subject to an absolute but rather limited protection. Although art. 17 of the ICCPR does not contain a permissible limitation clause, the Special Rapporteur on the promotion and protection of the right to freedom of opinion and expression recognizes permissible limitations on the right to privacy, subject to necessary, legitimate and proportionate restrictions. ${ }^{83}$

The three conditions of legitimacy, necessity and proportionality stipulated in the ICCPR are more specifically described by domestic courts. In the US, particularly in relation to exposing the records of public officers, the courts have interpreted the three conditions as follows:

[whether] the party seeking to come within the protection of the right to [privacy] ha[s] a legitimate expectation that the materials or information will not be disclosed"; "[whether] disclosure [is] nonetheless required to serve a compelling state interest"; and "[whether] the necessary disclosure occur[s] in that manner which is least intrusive with respect to the right to [privacy]. ${ }^{84}$

With regards to the first step of the inquiry, the PEPs as public officers are expected to have a lower level of legitimate privacy expectation than ordinary people. Thus, the suggested global AML/PEP regulatory body with pubic-private coordination, which shares the

\footnotetext{
${ }^{83}$ U.N. Human Rights Council, Report of the Special Rapporteur on the promotion and protection of the right to freedom of opinion and expression, Frank La Rue, at 8, A/HRC/23/40 (2013), available at http://www.ohchr.org/Documents/HRBodies/HRCouncil/RegularSession/Session23/A.HRC.23.40_EN.pdf. 84 Int'l Ass' $n$ of Fire Fighters, Local 1264 v. Municipality of Anchorage, 973 P.2d 1132, 1134 (Alaska 1999).
} 
information about PEPs, could be justified more easily when compared with sharing the same information about ordinary people.

Generally the information about a civilian—name, date of birth, identification numbers, address, phone number, and financial status, etc.--is regarded as protected PII of which access and disclosure is strictly limited, even though the privacy law of each state differs in its scope and level of privacy protection. ${ }^{85}$ Ordinary people have a legitimate expectation that the PII will not be disclosed. Thus, the PEP list is clearly a type of protected PII, but it is specifically about PEPS.

However, publication of the same information about public officers has been made legitimate in many cases. For instance, the laws of many states require public officers to declare their assets, which includes information about their name, address, account number and location of assets, etc., and to allow public access to such information, though to different degrees by states due to privacy concerns. ${ }^{86}$ Similarly, federal ${ }^{87}$ and some state laws ${ }^{88}$ in the US explicitly allow public inspection of information about state employees such as their names and position titles, their current and prior positions, the dates of appointment and resignation, etc. Even regarding the information about the public employee's home/work address ${ }^{89}$ or income of their family, ${ }^{90}$ the US courts have, in differentiating public employment from private employment, denied the reasonable privacy expectations of public employees.

\footnotetext{
85 Am. Jur. 2d, Privacy $\S 13$ ("It has been stated that the right of privacy is relative to the customs of the time and place, and is to be determined by the norm of the ordinary man. ...").

86 See World Bank \& U.N. Office on Drugs and Crime, Public Office, Private Interests: Accountability through Income and Asset Disclosure, at 84-93 (2012).

87 See 5 C.F.R. Part 293.311.

88 See AS 39.25.080; G.S. 126-23.

89 See Webb v. Shreveport (1979, La App) 371 So 2d 316, cert den (La) 374 So 2d 657.

90 See Humane Soc. of U.S. v. Fanslau, 54 A.D.3d 537, 863 N.Y.S.2d 519 (3d Dep't 2008).
} 
When the first inquiry is satisfied, the disclosure could be justified by passing muster of the second and third inquiries. In other words, even the protected PII information about PEPs, such as race, ${ }^{91}$ full birth dates ${ }^{92}$ or phone numbers ${ }^{93}$ could possibly be disclosed to satisfy a compelling state interest by employing the least privacy intrusive measure.

This part focuses on the third inquiry of the least intrusive measure since the second inquiry of compelling interest in disclosing the information about PEPs (i.e. deterrence of corruption and money laundering) is thoroughly described throughout this paper. ${ }^{94}$ The measures that are least intrusive to the privacy of PEPs would be employed with appropriate procedures to control to whom and how the disclosure should be made.

In the matter of to whom, it is suggested that the disclosure should be limited to the least number of parties required to accomplish the compelling interest of corruption deterrence. The best possible procedural measure in this respect would be to allow disclosure to financial institutions through the global AML/PEP regulatory body working as a centralized repository of an international PEP list.

Ideally, the privacy of PEPs would be best protected under the decentralized domestic PEP data center ${ }^{95}$ with each state establishing its domestic PEPs list and allowing direct access to both domestic and foreign financial institutions. This direct sharing would not involve unnecessary additional intermediaries, such as the global AML/PEP regulatory body, other

\footnotetext{
91 See CBS, Inc. v. Partee (1990, 1st Dist) 198 Ill App 3d 936, 145 Ill Dec 30, 556 NE2d 648, 52 BNA FEP Cas 1534, 17 Media L R 2051.

92 See Delaware County v. Schaefer ex rel. Philadelphia Inquirer, 45 A.3d 1149, 40 Media L. Rep. (BNA) 1670 (Pa. Commw. Ct. 2012).

93 See Office of Governor v. Raffle, 65 A.3d 1105 (Pa. Commw. Ct. 2013).

94 See II.A., pp.5-7.

95 This decentralized domestic PEP data center should be differentiated from the decentralized international PEP data center discussed in the prior section. See III.B.2.a., p.23.
} 
than domestic and foreign financial institutions who are the ultimate users of the information to deter corruption.

However, apart from the expected lack of accountability to other states, ${ }^{96}$ these decentralized domestic PEP data centers do not seem plausible. Each state would be required to maintain its own domestic PEP data center, which would be expected to incur high management costs. ${ }^{97}$ Much of the expensive costs incurred by each of 196 states worldwide are in fact an unnecessary overlap, which could be eliminated by having just one centralized international PEP data center. ${ }^{98}$

It is contended here that among the indirect sharing procedures, sharing through the proposed global AML/PEP regulatory body as an international PEP data center offers the best protection to the privacy of PEPs by minimizing the involved intermediaries. Although indirect sharing could be achieved instead through foreign states or public means (i.e. by each state establishing its domestic PEPs list and providing the list to foreign states whose financial institutions are authorized to access, or publicize the list so that financial institutions could access), both involve expansive disclosure of PEPs' personal information, thus being more invasive to the privacy of PEPs.

\footnotetext{
96 Due to its decentralization, decentralized international PEP data centers fail to secure accountability to other states. See id.

97 The data center is required to manage swift and secure access only to the authorized users of the information which are domestic and foreign financial institutions. Thus, the data center should continuously check and update its system to protect itself from unauthorized access such as cyber incidents while providing requisite information timely to financial institutions. Not all states are willing or able to manage the data center in such a manner.

98 This applies to a system of decentralized data center, whether domestic PEPs data or international PEPs data, managed by a state.
} 
More importantly, in the matter of how, it should be emphasized that the concern about privacy rights of PEPs could be significantly addressed by controlling the manner of access by financial institutions to PEPs' data.

For this purpose, it is proposed that the disclosure to financial institutions should be made via a case-specific reactive query matched against the information in possession of financial institutions so that the extent of the protected PII of PEPs disclosed to the financial institution could be minimized, or even eliminated. This contrasts with the expansive invasion to PEPs' privacy, potentially caused by the proactive disclosure where financial institutions access the raw input of PII of PEPs as a whole.

Under the case-specific reactive query match, to identify whether certain clients are PEPs or not, financial institutions would access the PEP data center by filling in PII information of the client (e.g. names, date of birth, identification numbers, address, phone numbers, etc.) under their possession presented voluntarily by the client to open an account. The PEP data center would then provide those financial institutions with the result of their specific query. If there is a hit-match against the query, the result would include only the information about the current and prior positions, the dates of appointment and separation, etc. of a specific PEP which is generally not regarded as information in relation to which public officers have a legitimate expectation of privacy.

\section{CONCLUSION}

Inclusion of domestic PEPs into the FATF Recommendations in February 2012 provides a cornerstone for fulfilling a high degree of coordination along two dimensions - the trans-border, and between public enforcement entities and private actors-required to minimize collateral damage to innocent PEPs like Mr. Ocampo and to maximize corruption 
deterrence. The trans-border coordination has been made through the reconciliation of the main substantive discrepancy on the scope of PEPs - whether to embrace domestic PEPs in addition to foreign PEP — in global PEPs standards.

However, the public-private coordination of two-way information sharing has thus far been lacking. While current global AML/PEP regulations require financial institutions to share their information with public authorities, none of them require governments to share requisite information in their possession — such as domestic PEP lists—with private financial institutions. To eliminate the causes of financial institutions' business judgement—-tremendous compliance costs and difficulties in identifying PEPs and an increased risk of serious fines for compliance failures — negatively affecting many innocent PEPs while maximizing corruption deterrence, it is essential that global AML/PEP regulations employ this public-private coordination of two-way information sharing.

This paper has shown that public-private coordination of two-way information sharing can be operationalized by mutual recognition for its basic framework. Under this principle of mutual recognition governing the recognition of foreign administrative decisions, the domestic PEP lists created by each government would be recognized by foreign financial institutions, and of course by domestic financial institutions.

For successful implementation of public-private coordination based on mutual recognition of domestic PEP lists issued by each state, the proposed global AML/PEP regulatory body establishing the global AML/PEP regulation should respect three essential values: accountability of states providing the domestic PEP list to foreign states, accountability to the listed domestic PEPs, and protecting the privacy of PEPs. To do so, the proposed global AML/PEP regulatory body needs to employ the following: institutional measures to establish 
a centralized international PEP data center with authority to audit and penalize cheating by states; procedural measures to control the different domestic PEP list making/review procedures of each state and to provide listed domestic PEPs with a direct channel of petition for review at the international level; and the procedural measures to allow financial institutions to access international PEP data center through a case-specific reactive query matched against the PII information of its client in its possession and to provide financial institutions only the result of the official position as a PEP.

If these recommendations are adopted, it is contended that the proposed global AML/PEP regulatory body and its regulations will attain legitimacy and effectiveness to deter corruption. It is about time to build on the cornerstone. 